\title{
Global suburbia and the transition century: Physical suburbs in the long term
}

\section{Citation}

Forsyth, Ann. 2013. "Global Suburbia and the Transition Century: Physical Suburbs in the Long Term." URBAN DESIGN International 19 (4) (October 2): 259-273. doi:10.1057/udi.2013.23. http:// dx.doi.org/10.1057/udi.2013.23.

\section{Published Version}

doi:10.1057/udi.2013.23

\section{Permanent link}

http://nrs.harvard.edu/urn-3:HUL.InstRepos:16143337

\section{Terms of Use}

This article was downloaded from Harvard University's DASH repository, and is made available under the terms and conditions applicable to Open Access Policy Articles, as set forth at http:// nrs.harvard.edu/urn-3:HUL.InstRepos:dash.current.terms-of-use\#OAP

\section{Share Your Story}

The Harvard community has made this article openly available.

Please share how this access benefits you. Submit a story.

Accessibility 


\title{
Global Suburbia and the Transition Century: Physical Suburbs in the Long-Term
}

2014 Urban Design International 19, 4: 259-273

Professor Ann Forsyth

Department of Urban Planning and Design

Harvard GSD

48 Quincy Street

Cambridge, MA 02138, USA

p. $617-496-3587$, f. $617-496-1292$

aforsyth@gsd.harvard.edu

Acknowledgements Background research was funded by the Clarence Stein Memorial Fund and the Lehman Fund for Scholarly Exchange with China. I thank Bonnie O'Neill for research assistance.

\begin{abstract}
Over the current century, when the world's population will grow by some billions, much of the increase in the human population will be housed in suburbs. However, sometime after the middle of this century the world's total population is also likely to level off, increasing in some areas while declining in others, causing new challenges. In this transition century, suburbs are a key technology and setting for managing a number of public concerns and problems: population change, aging, environmental issues, and tensions between continued poverty and expectations of affluence. Suburbs are very diverse internationally but share some common problems and opportunities related to their relative newness and outer location. While planned solutions to suburban growth are important, a great deal of work in the coming century will be retrofitting opportunistic suburban development. A global view of suburban growth is important because physical planning and urban design have long shared ideas internationally, and because of global economic, environmental, and cultural linkages.
\end{abstract}

Keywords: suburbs, global, future 


\section{Introduction: The Importance of Suburbs}

Beyond the core of every large urban area is a band of development called suburbs. What proportion of the urban or metropolitan area is seen as suburban depends on how one defines suburbs and such definitions are numerous. What is certain, however, is that over the current century, when the world's population will grow by some billions, a substantial part of the increase in the human population will be housed in suburbs. However, the story is complicated as toward the middle or end of this century the world's total population is also likely to level off, increasing in some areas while declining in others, causing new challenges for a planet that has become accustomed to growth. This decline is already happening in some metropolitan areas.

In this transition century, suburbs are a key setting and technology for managing a number of public concerns and problems about urban development. However, they are also where many people seek to live out their dreams and aspirations at the individual and household level. What are the opportunities and challenges posed by this coming wave of suburbanization, suburban shrinkage, and suburban redevelopment? In a century it is possible to alter what is the commonsense in terms of urban development but by then a very large amount of suburban development will be already built -is what is being put into place now adaptable to the future century's needs?

The paper first outlines how suburbs can be defined in a way that makes sense internationally-focusing on location and newness. It then examines potential changes in patterns of urbanization globally, and the role of suburbs in facing a slowing of growth, population aging, environmental problems, and issues of inequality. Planners have differing ideas about how to tackle these challenges. While there is something of a consensus vision in many urban design and planning circles of a sustainable, multi-centered, participatory metropolitan area that concentrates developments in accessible districts and respects the landscape, there is a lot of current and likely future suburban development that will not take that form (Reference 2; Loukaitou-Sideris, 2012). The paper reviews the range of common physical planning and urban design approaches to improving suburban areas at a smaller scale, the district, showing their diversity. It then proposes long-range global scenarios as tool that could be more widely used to imagine plausible futures and assess the quality of planning and design solutions at the building, district, and regional scales. Future suburbs need to be adaptable for growth, decline, or both over time. Urban designers need to understand and engage with these issues to be part of a continuing global conversation.

To make this argument I have to confront three potential objections. First, it can seem as if all (suburban) development is local so that a global view of suburbs is overdrawn. Suburbs are diverse enough within one country, let alone internationally. However, it is also obvious that local activities are connected not only nationally but in the global economy, the global environment, and in global culture. Patterns of development in one place have effects elsewhere. Planning, design, and development ideas are shared internationally among professionals, activists, and the wider public. Certainly some aspects of suburban development are very specific to a time and place-for example the substantial power of U.S. suburban governments to shape educational opportunities. But other topics are usefully examined in a global context, for example how to redevelop existing suburbs to be more sustainable or create new outer areas in a polycentric city. The problems and opportunities of outer location and 
relative newness - key features of suburbs--have certain similarities in many places (Harris, 2010).

The second problem is that to make this kind of argument I have to draw on (at least) three substantial bodies of literature that are often independent. First, is work on suburbanization and suburban character. This typically focuses on more affluent countries and includes scholarship from urban planning, history, sociology, geography, economics, and political science. Second, is the literature on urban development in lower and middle-income countries. This work often talks about peri-urban development or decentralization rather than suburbanization; discussions of suburbanization are often restricted to more affluent "Western" or "U.S.-style" suburbs which are seen as an expression of elite business practices and cultural influences. Finally, is a literature on global futures which seldom focuses on specifically urban futures. The differences in perspective are substantial. At least part of many interdisciplinary projects involves translating what is brutally obvious in one field into terms understandable in another and this is certainly the case here. However, to solve important problems scholarship (and practice) need to engage with these multiple dimensions. This will require some rapprochement from all sides although there are many encouraging signs (e.g. Audirac et al., 2012; Beard et al., 2008; Chattopadhyay, 2012; Clapson and Hutchinson, 2010; Gans, 2009; Harris, 2010; Song and Ding, 2009; Watson, 2009; Wu and Phelps, 2008).

The third issue is the ambivalence of many urban scholars and urban designers about suburbs. For example the substantial boom in U.S. housing production in the 1950s--when units constructed more than doubled over their levels in the half century before (Hise, 1997)--in turn sparked a more international wave of criticism of suburban culture, seen as conformist, isolating, and visually ugly. Titles like Lonely Crowd (1950), Organization Man (1956), Australian Ugliness (1960), and Feminine Mystique (1963) exemplified the general tone of such criticisms (Riesman, 1950; Whyte, 1956; Boyd, 1960; Friedan, 1963). A little later more practical concerns emerged about the problems of Traffic in Towns (1963) combined with larger discussions about Limits to Growth (1972) and the environmental and economic Costs of Sprawl (1974) (Ministry of Transport, 1963; Meadows et al., 1972; RERC, 1974). By the end of the century debates encompassed all these dimensions and had moved to an even more global stage with particular concerns about congestion, social connectedness (some saying there was too much in suburbs and others too little), social exclusion, conspicuous consumption, health, and placelessness (see reviews in Eichler and Kaplan, 1967, 4-10; Popenoe, 1977, 2-8; Gans, 1963; Forsyth, 2005; Harris, 2010). Of course some have defended suburbs either as a type or in terms of the more glaringly one-sided attacks (Breugemann, 2006; Barker, 2009).

Certainly these criticisms and defenses have been useful-often highlighting real concerns about suburban development or important blind spots and biases in debates. However, solving the problems of first housing substantial increases in urban residents and then managing suburbs with flat or declining, and aging and impoverished, populations requires more than critique. It also requires a view that looks beyond just the examples of the United States and Western Europe, or even of economically and culturally important global cities worldwide.

\section{What Suburbs Are}


Many people, of course, have fairly fixed views of what suburbs are, imagining rows of cookie cutter houses filled with nuclear families owning 2.1 cars. However, such locations are only a small proportion of suburbs-how small a proportion depends on the specific definition of suburbs one is using. For many people suburbs are defined by their built environment or activities, for example as places with many detached houses, as mainly residential in land use, or that are automobile-oriented (Turcotte, 2008). Others emphasize a culture, social order, or way of life (Harris and Larkham, 1999, 8; Johnson, 2006). In the U.S., suburbs are frequently defined as metropolitan municipalities outside the core city (Teaford, 2008). Others perceive suburbs as essentially white and affluent, making some think they are less deserving of attention-even though a vibrant literature on suburban history and sociology has pointed out the many exceptions to this characterization (Nicolaides and Wiese, 2006). Some environments-from squatter settlements in poorer countries to elite architect-designed houses in richer ones-are not considered by some writers to be suburban, even if they are clearly such in terms of location (Davis, 2006; Neuwirth, 2006).

In the international urban studies literature locational or temporal definitions of suburbs are often prominent-particularly definitions related to outer location, relative newness, and lower density (Reference 1; Harris, 2010). The first two characteristics in particular can be used to identify suburbs globally as they take into account the variety of suburban types from industrial suburbs to ethnoburbs (though they need to be stretched a bit to take account of older villages and towns swallowed up in suburban development). These dimensions lead to a number of similar characteristics of suburbs, for example problems with regional accessibility and the need to establish new social connections and physical infrastructure (either over time of at substantial initial cost) (Harris 2010).

This article takes this broader, more international view, defining suburbs in terms of their location and newness. In terms of location suburbs are on the outer parts of metropolitan areas, although that can be a very wide band in larger cities. They are new in the sense of most of their fabric having been built since widespread use of automobiles, motorcycles, motorized buses, and trucks. This provides a focus on what would often be called middle and outer rings of suburbs, and the suburban fringe. These are the frontiers of development - at the urban edge but also existing suburbs where the built fabric is aging or under stress. From cheaply built subdivisions, to large and hard-to maintain custom houses, under-serviced squatter settlements, aging high-rise social housing, and prefabricated warehouse space designed for use over a short time period, there are substantial mismatches between current or future needs and existing environments. However, whether one defines suburbs broadly or narrowly (e.g. as automobile-based outer residential development) there will be many suburbs built new, and still more redeveloped, in the current century. ${ }^{\text {ii }}$

\section{The Transition Century}

\section{Facing Uneven Growth}

These challenges that will be faced in suburbs in this century are in many ways unprecedented. The past century brought a massive increase in population from about 1.6 billion in 1900 to over six billion in 2000 (see Figure 1). In 1900 the average human lived just 31 years (50 in richer countries such as the U.S) (Cohen, 2006; Prentice, 2006). By 2000 average life expectancy had more than doubled (to 62 years for males and 67 for females) reaching more 
than 20 years beyond that in highly-urbanized places such as Japan, Singapore, and Australia (UN, 2004; CIA, 2011).iii Significant aspects of life that seem normal today-the presence of grandparents or long marriages-were not part of a world where most people died young.

\section{Figure 1: World Population Estimates Years 0 to 2000}

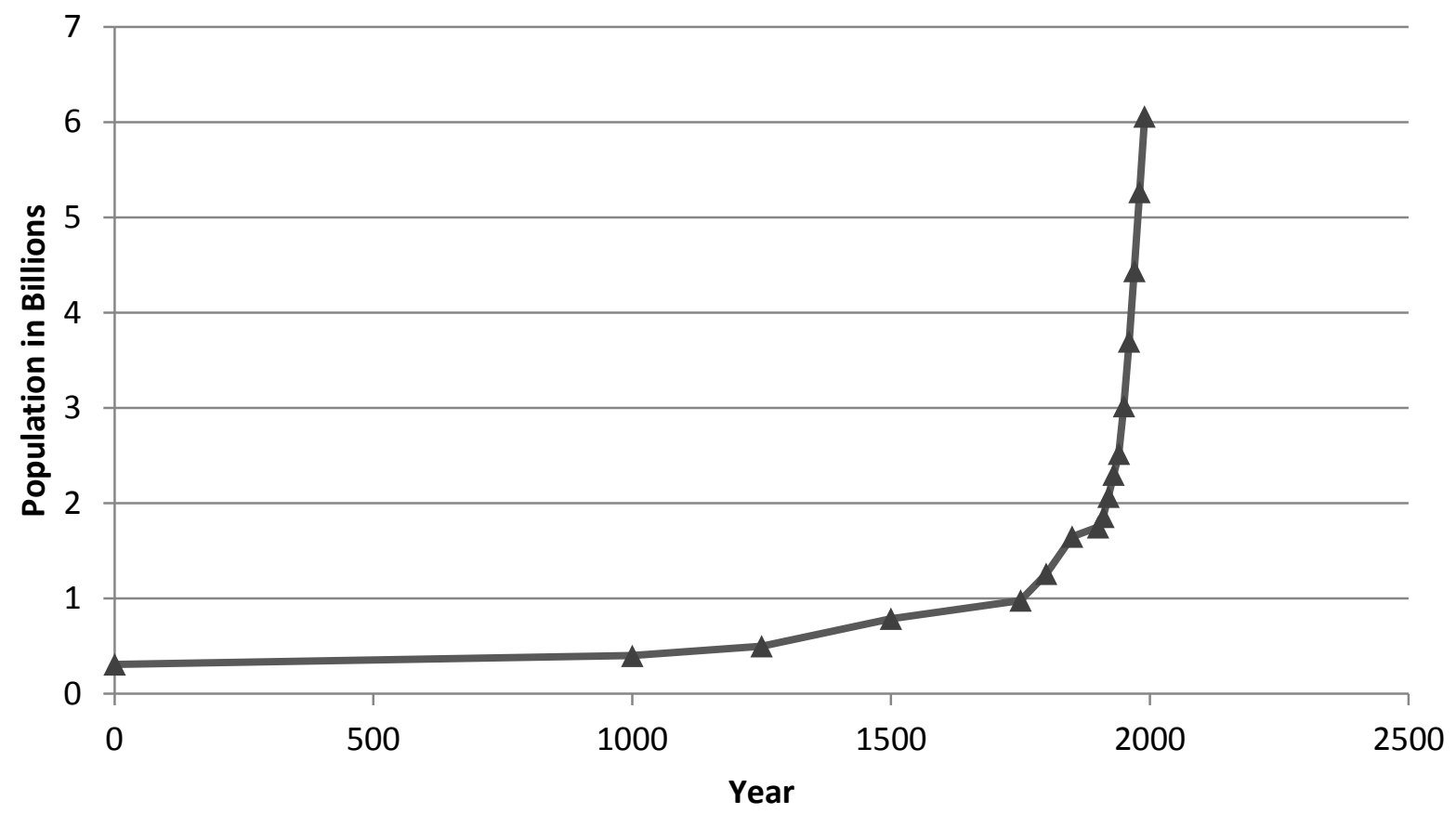

Source: Developed using UN (c.1999).

During the twentieth century an increasing proportion of the world's growing population moved to all parts of urban areas, including suburbs, rising from around $15 \%$ of the world's population in 1900 to about 50\% today (Satterthwaite, 2007a, v). By 2010 there were perhaps 50,000 "urban" settlements world-wide, where urban is defined as relatively compact settlements of at least a few thousand people with specific definitions varying by country (Satterthwaite, 2007a, 4-5, 2007b). In 1900 there were only 16 or 17 metropolitan areas of a million people or more (Chandler, 1987; Harvey, 1996, 403; Satterthwaite, 2007a, 6-7). Even using a restrictive U.N estimate, by 2010450 metropolitan areas had populations of a million or more (Satterthwaite, 2007a, 10, 2007b 12). . However, importantly for my argument there are literally thousands of settlements over 100,000 in population, making up approximately two thirds of the current world urban population (U.N., 2010, 5). These metros are quite large enough to have suburbs.

Much attention in urban scholarship focuses not on the many ordinary cities that house most of this urban population however, but on two other types, megacities and global cities (Robinson, 2002). Megacities, those with ten million or more people, made up only $5 \%$ of the world's population in 2000 (10\% of the urban population) and the proportion is not likely to increase much in coming decades (Satterthwaite, 2007b; U.N., 2010 5). ${ }^{v}$ Something similar can be said about the important economic and cultural centers or "global cities," locations such as Mumbai, New York, Tokyo, Sydney, Singapore, and Beijing (Global and World Cities, 2008; AT 
Kearney, 2010). Such places will certainly grow and have suburbs, have benefited greatly from globalization of the economy and culture (even if internally unequal), capture much academic attention, and have pleasant tourist bubbles. However, they will house a relatively small proportion of the world's population particularly relative to the large amount of attention they garner in the press and in scholarly circles (Robinson, 2002).

It is notoriously difficult to project future populations and the past is littered with examples of over and under estimates. ${ }^{\text {vi }}$ The U.N. projects that world population will increase by a middle value of 2.3 billion between 2009 and 2050, but that urban areas will gain 2.9 billion with the balance due to rural to urban migration. At that time the world would be almost 70\% urban (UN, 2010, 1; Montgomery et al., 2003, 4) (Figure 2). Assuming cities and towns maintain their positions as sources of job growth, most growth in the early part of the century will be in urban areas in low and middle income countries (see Figure 3). Asia already has half the world's urban population and Africa has more urban residents than North America. Looking a bit further in the future about one third of urban population growth from 2009 to 2050 will be in India and China (36\% to 2025, 31\% from 2025-2050) (Satterthwaite, 2007a, 3; U.N., 2010, 12; Figure 4). vii

Figure 2: World Population Scenarios 2000 to 2300 According to the United Nations

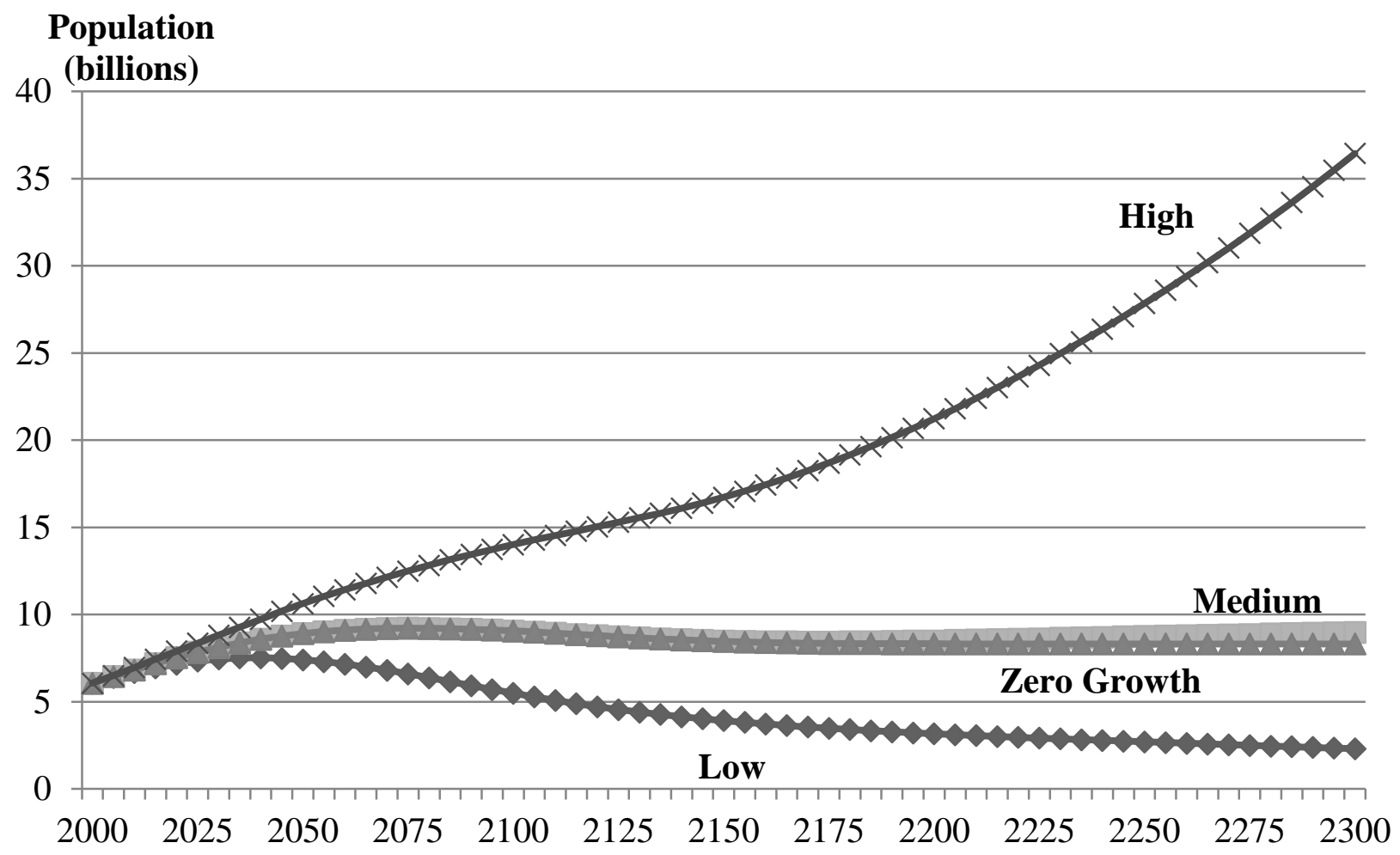

Source: Adapted from UN $(2004,8)$. 
Figure 3: From 2000 to 2030 Most Growth is Projected to be in Urban Areas in Middle and Low Income Countries

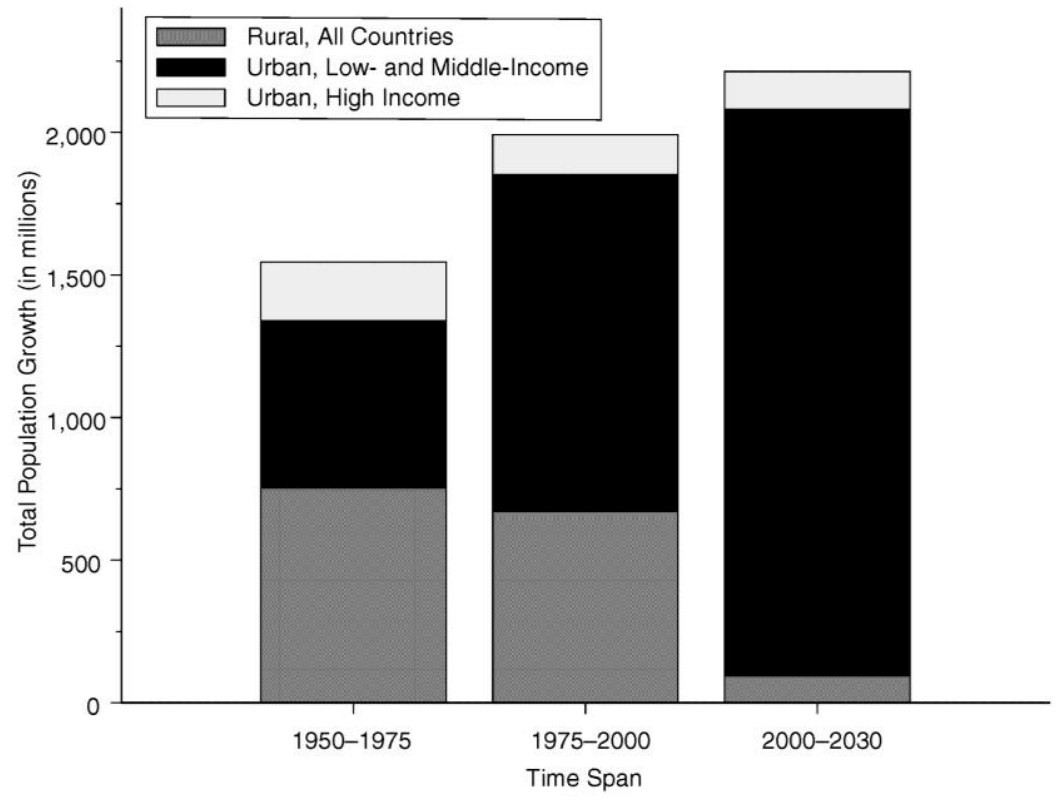

Original Caption" "Distribution of world population growth by urban/rural and national income level. Estimates and projections for 1950-2030.

Source: Montgomery et al. $(2003,13)$, using data from UN 2002.

Figure 4: Urban Areas over 750,000 with Fastest Average Annual Projected Growth 2000 to 2025

\begin{tabular}{llr}
\hline Urban Agglomeration & Country & $\begin{array}{r}\text { Annual increase } \\
\mathbf{2 0 0 0 - 2 0 2 5}\end{array}$ \\
\hline Foshan & China & $\mathbf{2 9 . 1 \%}$ \\
Yamoussoukro & Côte d'Ivoire & $16.7 \%$ \\
Ouagadougou & Burkina Faso & $14.8 \%$ \\
\hline Abuja & Nigeria & $12.2 \%$ \\
Lilongwe & Malawi & $10.5 \%$ \\
Kabul & Afghanistan & $10.0 \%$ \\
\hline Kigali & Rwanda & $9.6 \%$ \\
Shantou & China & $9.5 \%$ \\
Huizhou & China & $9.3 \%$ \\
\hline Blantyre-Limbe & Malawi & $9.1 \%$ \\
Sana'a' & Yemen & $8.6 \%$ \\
Luanda & Angola & $8.5 \%$ \\
\hline Huambo & Angola & $8.4 \%$ \\
Niamey & Niger & $8.4 \%$ \\
Nantong & China & $8.2 \%$ \\
\hline Putian & China & $8.1 \%$ \\
Kathmandu & Nepal & $7.9 \%$ \\
Dar es Salaam & U. Rep. of Tanzania & $7.7 \%$ \\
\hline Kampala & Uganda & $7.6 \%$ \\
Mbuji-Mayi & Dem. Rep. of the Congo & $7.5 \%$ \\
\hline
\end{tabular}


Source: Developed using UN2009b

The exact cities that grow will depend on many circumstances-from patterns of global investment to the shocks of natural hazards. viii But the basic point from lists such as those in Figure 4 is that many of these fast growing cities are not household names. This is more so the case with the many smaller cities not in this list because they were not yet at 750,000 population in 2009 when the data were compiled. And such metros will have suburbs-both broadly and narrowly defined-and including both economic activity (jobs) and residences (Hall, 1999). Figure 5 provides evocative examples of fast growing, important cities that are not household names globally.

\section{Figure5: Illustrations of Fast Growing Cities}

City: Ghaziabad India (\#2*) is a satellite city of Delhi ( $20 \mathrm{~km}$ away) and soon to be linked through the new metro system. With a population of about 1 million it is a manufacturing center that was named the "hottest city" in India in 2006 by Newsweek (Raaj 2006; National Informatics Centre 2011). Illustrations show advertisements for new high rise housing, a garbage dump in the middle of the built-up area, and a new shopping mall.
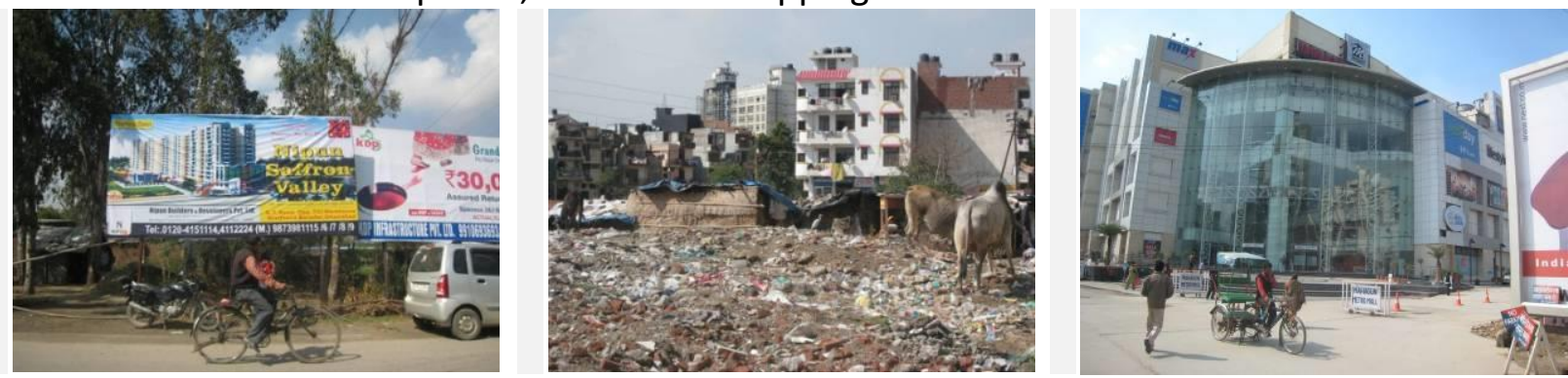

City: Heze China (\#68*). The population of the actual city is not clear but it is part of a larger City of Heze region of over 12,000 square kilometers with a population of over 9 million (many Chinese Cities have such generous boundaries [Cohen 2006, 66]). Located mid-way between Shanghai and Beijing it has a number of industries including agriculture; manufacturing; oil, coal, and gas mining (Shangdongbusiness.gov.cn n.d.). Illustrations show local farmers selling vegetables in a vacant lot, new development on the urban edge, and vendors outside automobile show rooms on the urban edge.

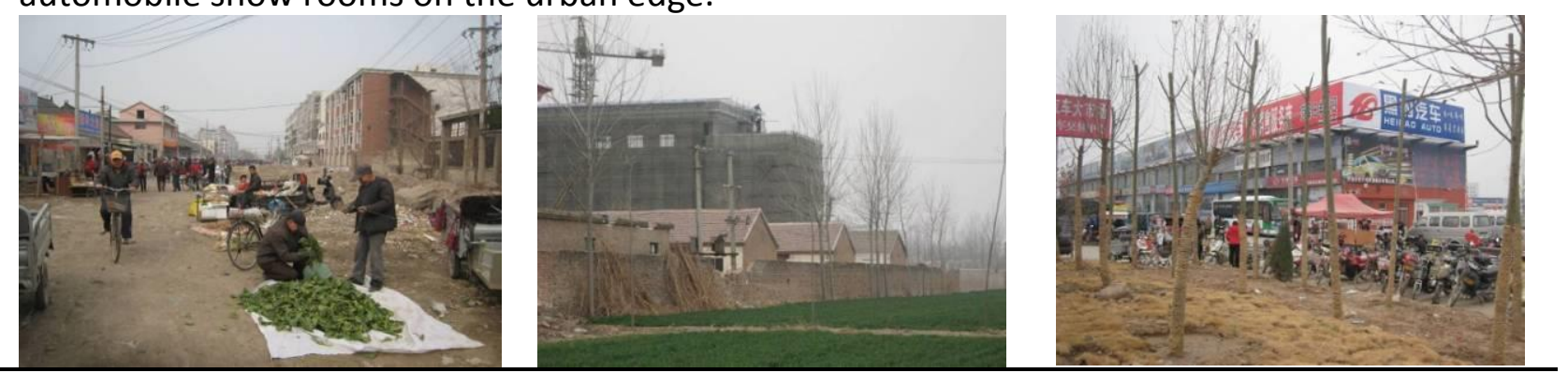

${ }^{*}$ Ranking from CityMayors.com 2006, a plausible but different list to the U.N figures for metropolitan areas over 750,000. 
While projections assume that populations will increase in the near term, many "middle" and "low" projections also chart a challenging new course where sometime between the middle and end of the century a new trend will emerge-global population growth will slow and perhaps even stop (UN, 2004, 2; Montgomery et al., 2003; Satterthwaite, 2007a, 2007b, 28). Population shrinkage is already being faced in some metropolitan areas, due to uneven patterns of investment, but may well become pervasive (Martinez-Fernandez, 2012). ${ }^{\text {ix }}$ Certainly even with a flat population people could move to locations with more opportunities and household size could drop, necessitating more building, but the last century's pattern of relentless expansion will slow. The world has been growing for the contemporary planning profession's entire history-and certainly for the briefer history of the contemporary form of urban design - this transition is a major change (Krieger 2006). Suburbs, which have often grown at the expense of core cities, will themselves shrink.

\section{Challenges for Suburbs}

Combined with the other global problems of environmental damage and inequality, these demographic changes present four major sets of challenges that will have key sites in suburbs.

Uneven growth: Whether short-term (30-year) urban growth is enormous or just very large, metropolitan areas will face difficulties. Many will grow, a lot, and then slow; a few will decline in population fairly constantly; some will have uneven expansion. In a world that has been rapidly growing for over 200 years this is a fundamental change. Many of the places that face these challenges will be smaller metropolitan areas or suburban municipalities. Even in richer countries they may not have fully developed urban governance with implications for providing infrastructure-from clean water to transportation-and coordinating regional growth (Satterthwaite, 2007b, 57). Urban design interventions are likely to be piecemeal and fragmented.

Practically, it is complicated to plan for both growth and continuity or decrease but the time horizon is long. Some decline will be dramatic-like the loss of population in New Orleans after Hurricane Katrina-but many other examples will involve slow emptying of populations as in parts of the former Soviet Union or the U.S. rustbelt. For a while, the incredible growth in places like China will be hard to ignore. Growth is captivating. It needs to be put in perspective, however.

Longer lives: The twentieth century brought dramatic changes in women's roles; in the $21^{\text {st }}$ there are likely to be equally major changes around aging (Castells, 1997). In $200010 \%$ of the world's population was over 60 . The medium UN projection is for $30 \%$ in 2100 with an average life expectancy in the 80s. The ratio of children and elderly to working aged people (1559) will increase from 0.67 to 0.88 over the century (UN, 2004, annex). In a world where social, and urban, systems have been set up under the assumption that there will be many working aged people for every retired person this is a change. ${ }^{x}$

By the end of this century basically all locations in the world-even Africa, a demographically young continent--will likely have a population dominated by those over 40 and with substantial numbers in their 70s, $80 \mathrm{~s}$, and above. Around the world suburbs have offered younger people less expensive housing; in a world where most people are older they will have a different role. ${ }^{\mathrm{xi}}$ 
Even with healthier aging this is a large change--in family life, social support, retirement incomes, and in how people interact with places including suburbs. Here outer location is likely the most crucial issue; some suburbs will be well placed for older people who can no longer drive or who need other support. Houses might be large enough for intergenerational or group housing; many suburbs have vibrant and convenient town centers. They can be redeveloped at a human scale. But many suburbs will need extensive retrofitting and some may be just too expensive to service with implications for the possibilities of aging in place.

Damaged natural environment: Environmental damage has been a key concern of urban planning for some decades. Environmental planning is a major specialty in most professional programs. As such there has been substantially more thought paid to it than the population transitions above (Chapin, 2012).

However, this area has some specific interactions with suburbs-new suburbs bring people closer to rural lands and natural areas, providing a naturalistic urban design character, but they also use up such areas. Development in suburbs will have implications energy use, levels of local pollutants, and opportunities for sustainable employment (Berke, 2009; Newman and Kenworthy, 2000). Probably the strongest and most internationally-valid critique of suburbs is that they overuse resources-land, energy, water. Solutions, however, cannot realistically just involve re-urbanizing the core cities but will also involve work in suburbs; and ideas for ecologically sustainable suburbs, while provocative and useful, have not yet grappled enough with other trends such as aging (Pillemer et al., 2011).

Continuing poverty and heightened expectations: Since 1980, according to some accounts, there have been reductions in the number of very poor world-wide, and global income inequality has declined slightly. However, wages are becoming more unequal globally (wages are only part of household income) and there is increased within-country inequality in several major nations including the U.S., China, and India (Dollar, 2005). Many hundreds of millions of urban dwellers still lack clean water and connections to sewer systems; others live in crowded conditions and shacks or on land subject to flooding and landslides.

Globally many of the poor live in suburbs due to the lower cost of land. The international suburban and housing literatures has a long tradition of work on suburban disadvantage and isolation (e.g. Maher, 1994; Moran, 2011; Orfield, 2002; Audirac et al., 2012; Hebert et al. 2012).

However, much of the recent literature specifically on suburbs in a global perspective has focused on elite, gated, and what are termed "U.S. - style" suburbs (Fishman, 2003; Liechenko and Soleki, 2005; Xue and Zhou, 2007; Lara, 2011). These represent substantial affluence, are typically inhabited by people aware of global trends, and are certainly important. Business growth relies on selling more things and experiences to more people (Castells, 1997; Knox, 2005; Marcuse and van Kempen, 2000). Suburbs are important locations because they are areas where extensive development occurs and dwellings are typically larger than in core cities. Even in more modestly produced areas suburban development can absorb a lot of products.

However, while such elite suburbs are important both poverty and affluence will play a role in suburbs. I call this issue one of inequality but it is much more than that in reality-it is part of an uneven economic landscape (Marcuse, 2006). That both poverty and affluence happen in suburbs muddies international discussions-particular debates tend to focus on one 
or the other. But both are strongly present in suburbs and provide important, though different, challenges for urban designers and planners.

\section{Evaluating the Physical Planning Toolkit: Built Environment Framing Implementable Answers}

What can urban designers and planners do to meet the challenge of this suburban future? What are the special implications for suburbs beyond those generally brought about by urbanization as a whole? In the physical planning and urban design toolkits, what strategies are available? Can suburbs, as major growth components of urban areas, be developed and redeveloped to provide solutions for these urban challenges that will work in enough places to make a difference?

This is not a situation with very easy answers. As has been demonstrated in numerous fields, from history to game theory, important human aims--such as global sustainability and personal aspirations for a good life--are not intrinsically in harmony. This creates the potential for a significant clash between, in this case, what people need to flourish in the way they have come to understand that term, and what the planet needs to survive in a way that is relatively intact (Ignatieff, 1984). Around the world there are obvious examples of this problem-eroding landscapes, lost habitat, polluted water, and social dislocation. Some places manage to coordinate growth in a way that provides opportunities and a high quality of life for most residents, but many do not (Hall, 1999; Watson, 2009).

This inquiry is both helped and made more complex by the substantial variety among existing suburbs from elite suburbs in global cities to self-build homes and mass produced apartments. People with low incomes can buy inexpensive--if unserviced and inaccessiblesuburban land and build a home gradually. Affluent people can buy large amounts of land for uniquely designed homes close to natural features. There is a long tradition of transit-oriented suburbs served by trolleys, railways, and special buses; densities in these areas can be very high. Some suburbs are very diverse physically and socially - with ethnic clusters, diverse incomes, or lifestyle enclaves. Some suburban areas started up as independent towns but came to function as suburbs as they were surrounded by development. There are many variations-different in look, amount of development, regulations, income level, social arrangements, and so on (Reference 1).

Solutions also differ for in several other important dimensions:

- Scales of activity: the region or metropolis, the district, and the building. These scales involve different actors - from residents to regional governments-and different strategies from green building to regional plans. Innovative ideas that may be achievable at a small scale and attractive to a select group of people may not sell to tens or hundreds of thousands of people or, if regulations, may not have the potential to be applied broadly beyond one neighborhood or city.

- Types of development: these include completely new land conversion, replacement of existing buildings, and renovations or adaptations. Using data from 2000, Nelson (2004) projected that by 2030 nearly half of the buildings in the United States would have been built in the previous 30 years and almost $40 \%$ of this would be replacement of existing structures; commercial and industrial buildings in particular tend to have short lives (see Figure 6). While likely delayed by the recession, this demonstrates the huge scale of 
potential development in coming decades even just looking at replacement; in growing areas the extent of development is even larger.

Figure 6: In the United States, a Substantial Amount of Building will need Replacement in Coming Decades

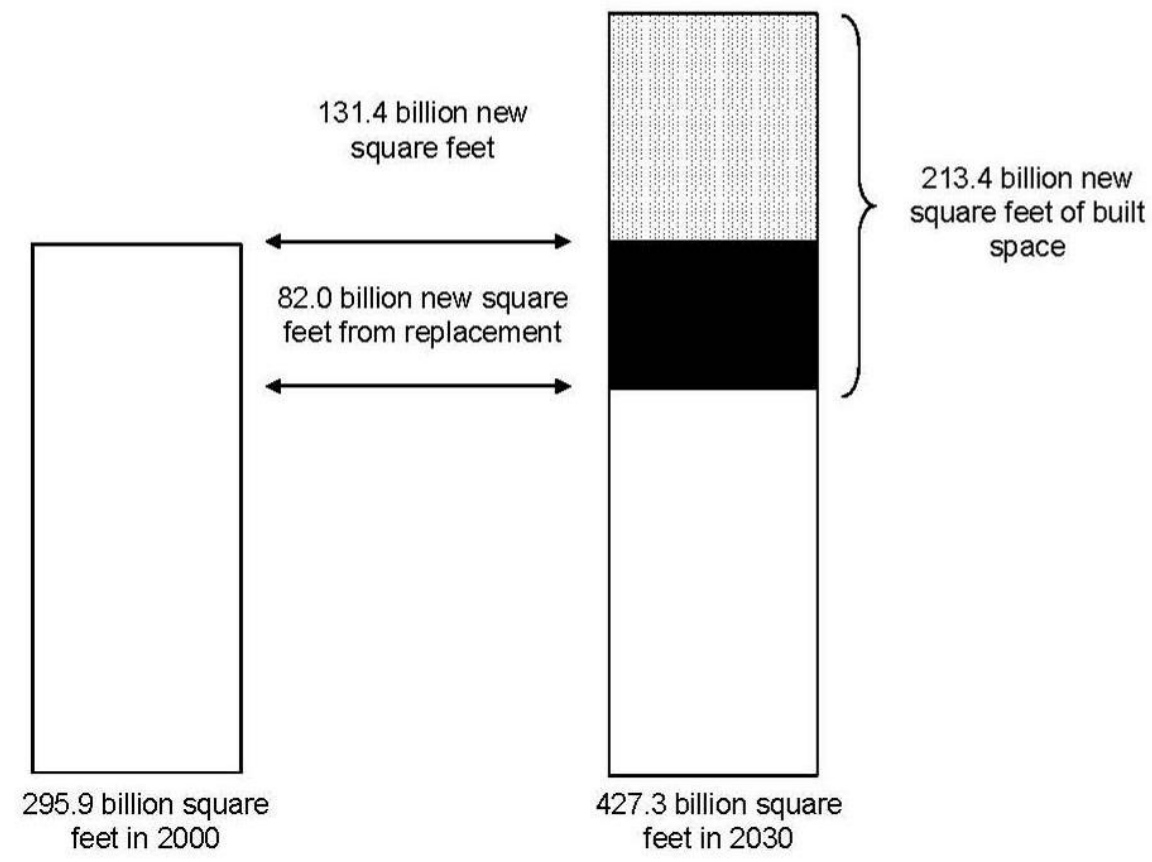

Original Caption: "Amount of Square Feet of Built Space: 2000 and 2030. " Source: Nelson 2004

- Adaptability to change over time: As changes occur, built places need to be flexible enough to allow other uses, amenable to being efficiently rebuilt, or perhaps designed to be gracefully abandoned. Basically all of the well-loved urban places in the world have gone through multiple stages of rebuilding or have inbuilt flexibility (think of the ways urban cores have been redeveloped numerous times, for different users and purposes, with the same street patterns and even the same basic building types). Regulation may stifle positive change; a lack of it can provide so little coordination that there is a lot of waste.

\section{Current Options}

Worldwide there will of course continue to be a great deal of opportunistic development that is minimally regulated or reflects political and economic connections over the public interest (Watson, 2009). It is not just a matter of McMansions sprawling across farmland in the U.S. but of high rise apartments popping up in unserviced paddy-fields elsewhere. There is a lot that is positive about self-built housing in suburbs but also long-term challenges in providing services and real problems if such housing is built on hazardous land. In areas where suburbia has lower densities some solutions may need to reduce densities even more and take some forms of development back to nature. In places where suburbs have very high densities the problem to solve may be providing adequate infrastructure and retrofitting 
universal design as people age (not as simple as it sounds in many locations). There will be much of this kind of opportunistic development in coming decades so finding solutions to retrofitting it will be important.

When looking at more planned responses to suburbanization, however, urban planners and designers are also divided on how to improve upon this current situation. In this section I look at the scale of the district-between the building and the region. These last two-the building and the region-are very important. The district scale, however, is a key part of public and professional debates (e.g. it is a scale that design professionals understand and journalists write about). It also arguably has less of a consensus compared with arguments for green and efficient buildings on one hand and coordinated regional plans (with multimodal transportation corridors in a multi-centered urban form respecting important landscape features) on the other (Reference 2). Of course divided opinions are often for good reasons, because different places have different challenges. But they may also represent the mismatch between traditional scholarship and practice in this area, and the fast pace and global reach of this change.

In Figure 7, I list a number of the most common approaches to improving areas at this scale, and assess their problems and benefits. In doing this I look back to the four challenges for suburbs (uneven growth, aging, environmental damage, inequality) and the implementation issues of scale, development type, and adaptability (Figure 7; see figure 8 for examples of current suburbs).

Figure 7: Examples of Ranges of Planned Approaches to Physically Improving Current Suburbs and New Suburban Developments

\begin{tabular}{|c|c|c|c|}
\hline Big idea & Examples & Problems & Opportunities ${ }^{\text {b }}$ \\
\hline \multicolumn{4}{|l|}{$\begin{array}{l}\text { Incremental (one system } \\
\text { or building at a time ) }\end{array}$} \\
\hline $\begin{array}{l}\text { Infrastructure } \\
\text { improvement: Upgrading } \\
\text { of under-serviced areas }\end{array}$ & $\begin{array}{l}\text { Squatter settlement } \\
\text { upgrading, } \\
\text { infrastructure } \\
\text { improvements; } \\
\text { transportation retrofits }\end{array}$ & $\begin{array}{l}\text { May reinforce spatial } \\
\text { inequalities/locational } \\
\text { disadvantage, } \\
\text { environmental hazards }\end{array}$ & $\begin{array}{l}\text { Low initial cost (unserviced) } \\
\text { followed by improved services } \\
\text { can match costs to revenues; can } \\
\text { provide more green } \\
\text { transportation }\end{array}$ \\
\hline $\begin{array}{l}\text { Consolidation / } \\
\text { reurbanization: } \\
\text { intensifying development }\end{array}$ & $\begin{array}{l}\text { Granny flats, replacing } \\
\text { 1-story commercial } \\
\text { with mid-rise }\end{array}$ & $\begin{array}{l}\text { May intensify in areas } \\
\text { without services; some } \\
\text { areas are expensive to } \\
\text { retrofit for universal } \\
\text { design to support an } \\
\text { aging population }\end{array}$ & $\begin{array}{l}\text { Saves land; can promote } \\
\text { development near transit; allows } \\
\text { development to respond to near- } \\
\text { term and changing needs }\end{array}$ \\
\hline \multicolumn{4}{|l|}{$\begin{array}{l}\text { Planned at the district } \\
\text { level }\end{array}$} \\
\hline $\begin{array}{l}\text { Efficiency: } \\
\text { Compact/sustainable } \\
\text { cities; concentrated } \\
\text { centers linked together by } \\
\text { efficient transportation }\end{array}$ & $\begin{array}{l}\text { Ecocities, transit- } \\
\text { oriented development, } \\
\text { compact cities, aspects } \\
\text { of smart growth }\end{array}$ & $\begin{array}{l}\text { Needs a great deal of } \\
\text { coordination which is } \\
\text { easier in some places } \\
\text { than others }\end{array}$ & $\begin{array}{l}\text { Fewer new suburbs needed; can } \\
\text { improve existing areas; a multi- } \\
\text { faceted approach }\end{array}$ \\
\hline $\begin{array}{l}\text { Nature: Ecoburbs bring } \\
\text { people closer to nature }\end{array}$ & $\begin{array}{l}\text { Lower density garden } \\
\text { suburbs, leafy } \\
\text { enclaves, eco villages }\end{array}$ & $\begin{array}{l}\text { Can spread out the city } \\
\text { undermining other } \\
\text { goals }\end{array}$ & $\begin{array}{l}\text { Liked in many cultures: on-site } \\
\text { energy generation, water } \\
\text { treatment, food }\end{array}$ \\
\hline
\end{tabular}




\begin{tabular}{|c|c|c|c|}
\hline Big idea & Examples & Problems & Opportunities ${ }^{\text {b }}$ \\
\hline $\begin{array}{l}\text { Diversity: Social diversity, } \\
\text { social cohesion }\end{array}$ & $\begin{array}{l}\text { Scattered site urban } \\
\text { public housing; ethnic } \\
\text { clusters }\end{array}$ & $\begin{array}{l}\text { Physical design is } \\
\text { perhaps not the best } \\
\text { way to achieve social } \\
\text { ends }\end{array}$ & $\begin{array}{l}\text { More efficient and fair i.e. } \\
\text { overcomes problems with access } \\
\text { for disadvantaged groups to } \\
\text { spatial opportunities; may help } \\
\text { social bonding }\end{array}$ \\
\hline $\begin{array}{l}\text { Commonality: Common- } \\
\text { interest enclaves }\end{array}$ & $\begin{array}{l}\text { Eco villages, } \\
\text { retirement } \\
\text { communities, gated } \\
\text { enclaves, co-housing }\end{array}$ & $\begin{array}{l}\text { Large exclusive areas } \\
\text { can fragment the } \\
\text { metropolis }\end{array}$ & $\begin{array}{l}\text { Efficient service provision for } \\
\text { those with special needs; social } \\
\text { interaction }\end{array}$ \\
\hline $\begin{array}{l}\text { Place: Creating a sense of } \\
\text { place related, often, to } \\
\text { traditional building and } \\
\text { street types }\end{array}$ & $\begin{array}{l}\text { New urbanism, urban } \\
\text { villages; suburban } \\
\text { town center } \\
\text { development }\end{array}$ & $\begin{array}{l}\text { Can ignore social } \\
\text { problems }\end{array}$ & $\begin{array}{l}\text { Locally more walkable; can make } \\
\text { compact city approaches more } \\
\text { acceptable; increase variety in } \\
\text { terms of housing options; } \\
\text { reconceptualize suburban areas } \\
\text { as places in their own right not } \\
\text { just adjuncts to the core city }\end{array}$ \\
\hline Growth: Economic engine & $\begin{array}{l}\text { Technopoles, industrial } \\
\text { and research parks, } \\
\text { distribution centers, } \\
\text { edge cities }\end{array}$ & Not always sustainable & $\begin{array}{l}\text { Economic opportunities; mixed- } \\
\text { use }\end{array}$ \\
\hline $\begin{array}{l}\text { Developed by reflecting on } \\
\text { 2009; Grant and Mittelstec } \\
\text { Kenworthy,2000; Newmar } \\
\text { a There is also a great deal } \\
\text { b. See section on "Challeng } \\
\text { explanation. }\end{array}$ & $\begin{array}{l}\text { Berke, 2009; Biddulph, } 20 \\
\text { It, 2004; Krieger, 2006; Lc } \\
\text { et al.,2009; U.N., Habitat } \\
\text { f work that develops one } \\
\text { for Suburbs" for explan }\end{array}$ & $\begin{array}{l}\text { 0; Dunham-Jones and W } \\
\text { ng, 2005; Osborne and W } \\
2010 . . \\
\text { building at a time to refle } \\
\text { tion. and "Framing Impl }\end{array}$ & $\begin{array}{l}\text { liamson, 2000; Forsyth and Crewe, } \\
\text { ittick, 1977;Newman and } \\
\text { t individual preferences. } \\
\text { mentable Answers" for }\end{array}$ \\
\hline
\end{tabular}


Figure 8: Some of the many faces of Global Suburbs

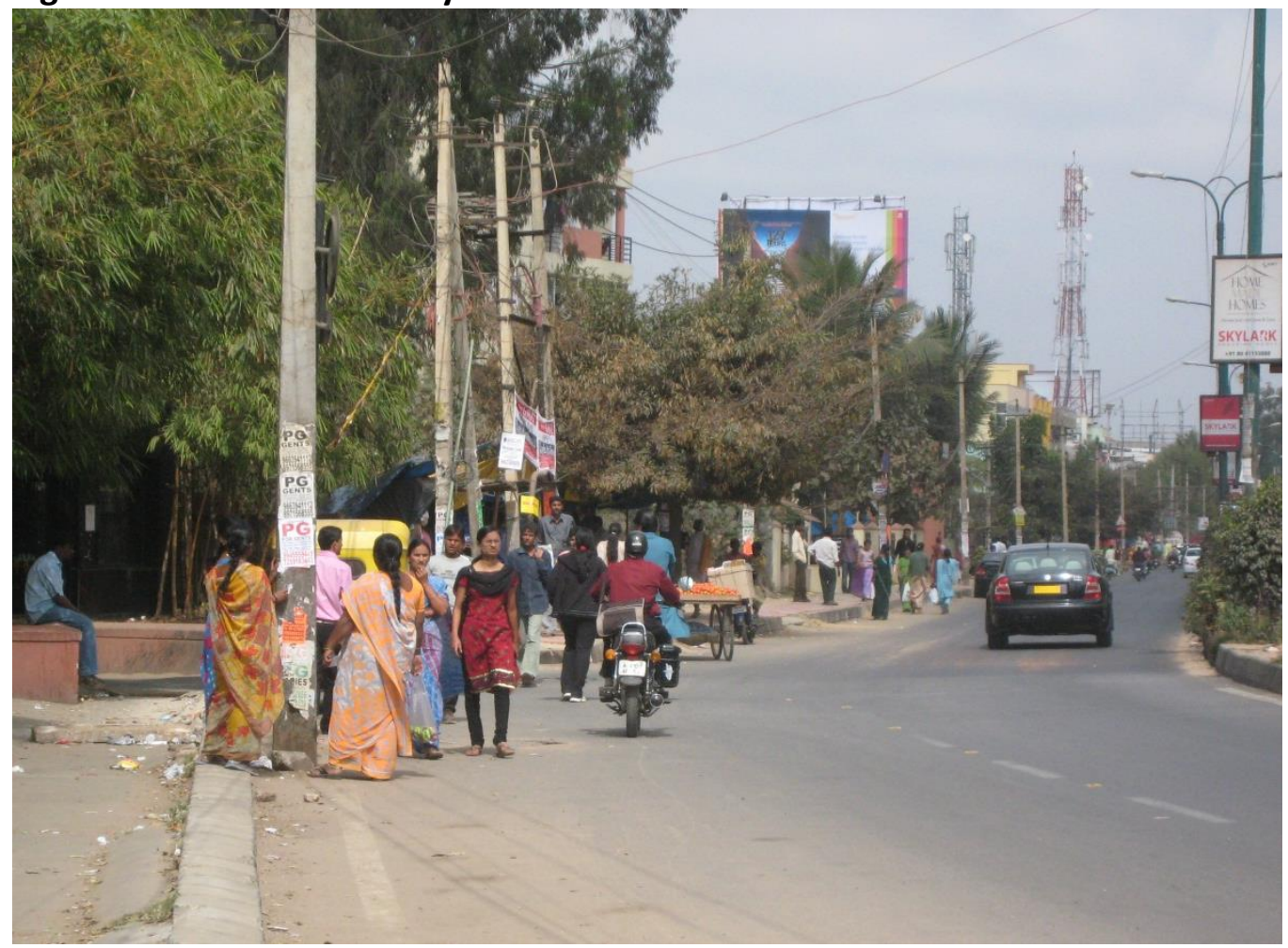

Suburban Whitefield outside Bangalore, India, in a high tech area.

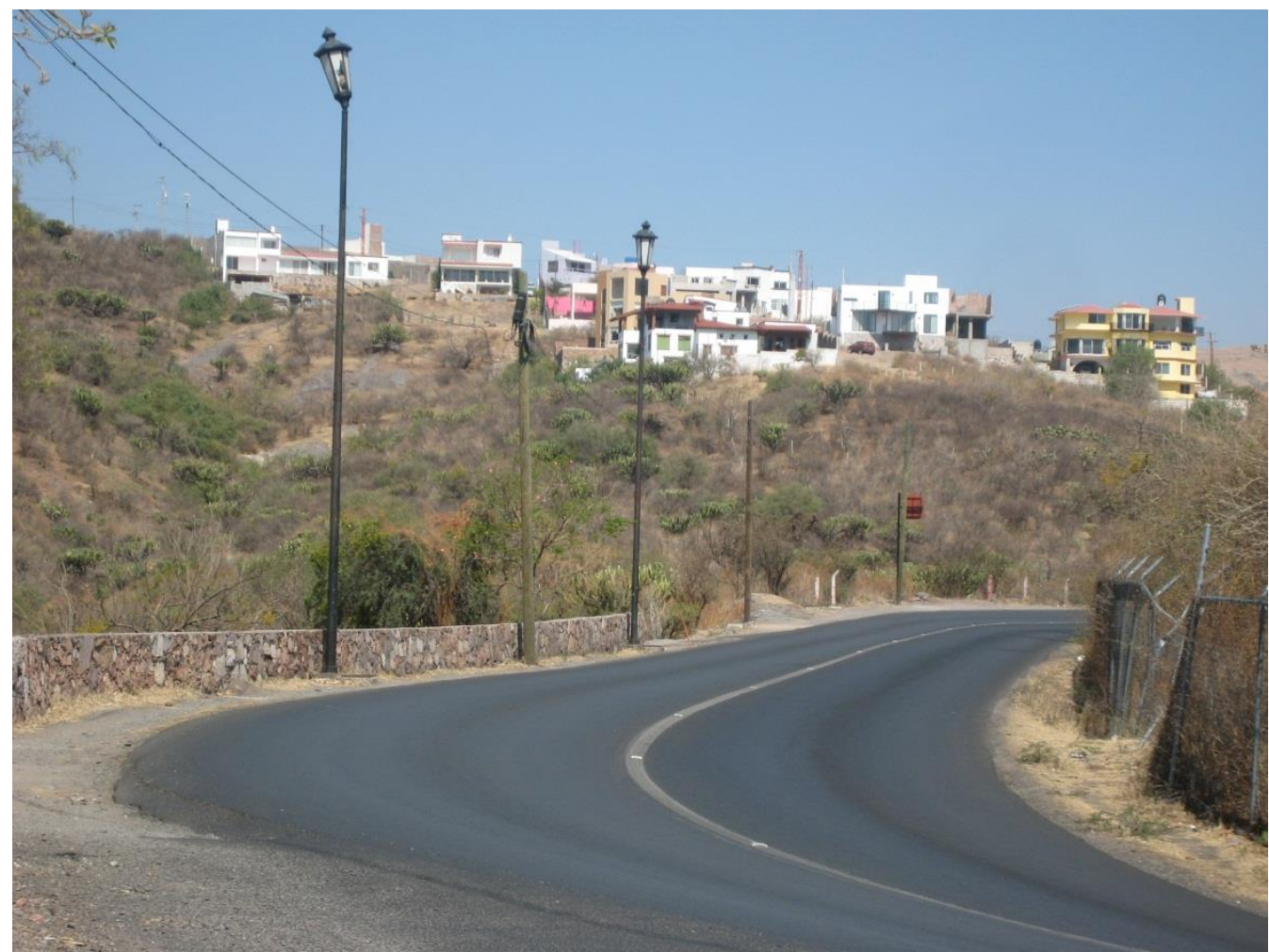

Suburban Guanajuato, Mexico, showing hillside development. 


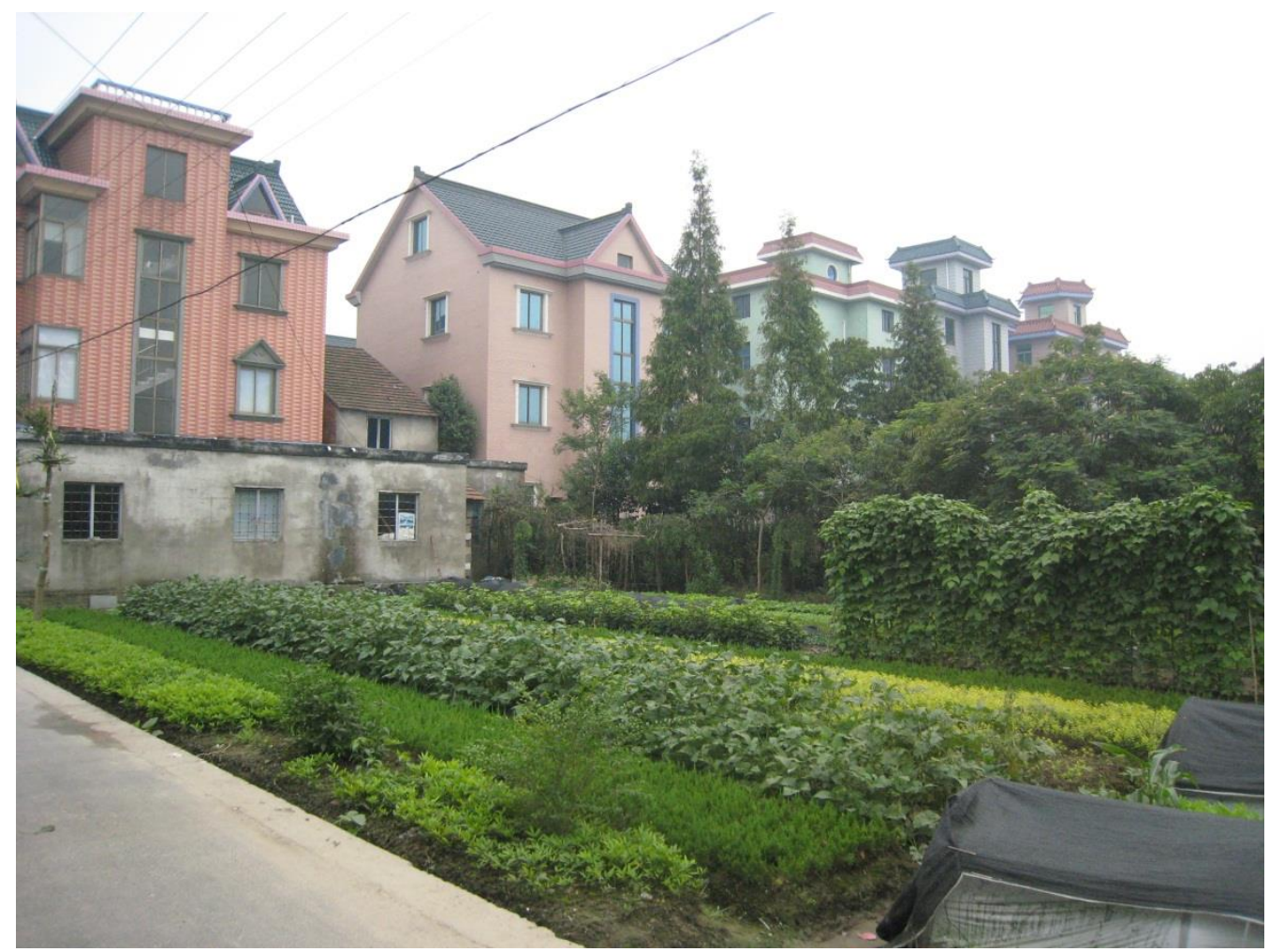

Suburban Hangzhou, china, showing intensification of agricultural areas.

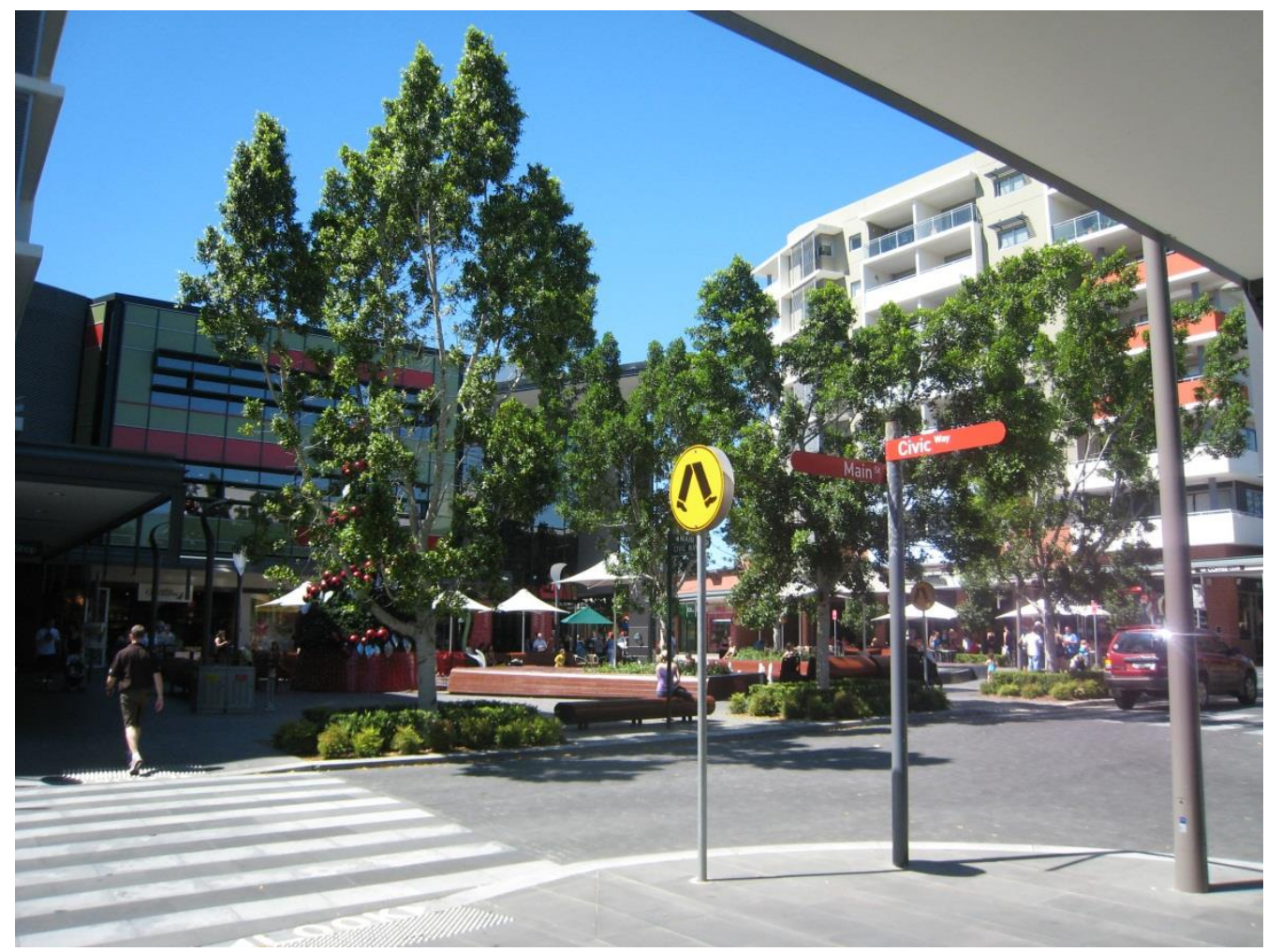

A town centre in outer suburban Sydney, Australia. 
Some planned approaches are more incremental though conforming to some set of overall regulations, or regional plans. Approaches that intensify development in particular areas, perhaps those well serviced by public transport, can help make development more efficient. Intensification strategies lead to less need for new suburbs. Around the world, even in richer countries, many suburbs have been developed with rather modest initial services and these were upgraded later. For example, both in the U.S. and Australia many suburbs of the 1940s and 1950s were developed using septic tanks that were then replaced in a more coordinated manner (Hayden, 2003). While more expensive to retrofit, and not taking full advantage of the potential for infrastructure to shape suburban form, it has a long history. Better approaches will be needed internationally for such upgrading.

Urban designers thinking about solutions to urban problems often think of more focused solutions such as those in the second half of the table. These try to solve key perceived problems of suburbs such as placelessness, homogeneity, a lack of appropriate services, or a lack of jobs (e.g. Vall-Casas et al.. 2011). They create imageable places and can be highly influential, though to make a major positive difference in suburbs they typically need to be part of a larger regional system. . $^{\mathrm{xii}}$ They are not all equivalent, however. Those seeking or promoting access to nature, a sense of place, or economic growth alone can command many resources and have a big impact without engaging much with the challenges of aging, environmental damage (particularly efficient transportation), or inequality.

There is also of course a range of community development, social life, and governancefocused approaches not listed in Figure 7--from suburban poverty alleviation and participatory budgeting to small business training and land regularization. Given the large social changes envisaged, these non-physical methods will be important and perhaps easier to implement than changes to the built environment. However, assessing which ones will be effective in improving suburbs is still a problem (Watson, 2009).

\section{Testing Scenarios}

Rather than try to evaluate approaches such as those in Figure 7 in terms of abstract principles one can also think about how they might engage alternative possible futures. Of course, there have been many inaccurate predictions about the future. One approach to managing this situation is to create plausible scenarios about a range of possible futures and design strategies that can cope with both the alternative general futures and the specific suburban challenges: uneven growth; longer lives; environmental damage; and the tensions around inequality. Better suburban solutions would be able to weather the worst scenarios and help fulfill the best.

What might a very long term scenario look like? A number of bodies build such scenarios that combine projections and forecasts with stories about possible futures (Chakraborty, 2011; Myers and Kituse, 2000; Quay, 2010). I use just two existing examples to show some of the range. Royal Dutch Shell is famous for creating scenarios so it can plan its very long-term land and infrastructure investments (Wack, 1985). It does these fairly frequently and in 2008 developed its "scramble" and "blueprint" scenarios for 2050.

- Scramble: Countries focus on their own energy security with bilateral deals; coal and biofuels increase; carbon production increases; and climate and political instability result. 
- Blueprint: This scenario involves more regulation, initially led by specific cities and regions, and carbon trading matures early. This is a more stable scenario with more affordable energy prices (Shell, 2008).

These are not necessarily desirable futures but rather possible ones that a company needs to be ready for. By 2050 blueprint uses only $15 \%$ less energy than scramble, however (Shell, 2008, 46).

The Global Scenario Group run by NGOs in Sweden and the U.S. has worked on a wider range of scenarios ending in 2100.

- "Market forces" and "policy reform" have much in common with scramble and blueprint in that the world evolves "without major surprise[s]" (Raskin et al., 2002, 14).

- Two more focus on deteriorating situations--an authoritarian and gated "fortress world" and a more dramatic "breakdown" where multiple crises lead to the collapse of institutions, economies, and cities.

- A final two, that they call "great transitions" are more focused on sustainability: "ecocommunalism" is a vision of local democracy and bioregionalism; "new sustainability" is more positive about urban life and global links and will be more recognizable to planners (Raskin et al., 2002; see similar range in Newman et al., 2009).

Obviously, these scenarios are developed at least in part to promote the last two rather than to have people prepare for literally all of them.

These are certainly not the only possible scenarios but they give a sense of the range of current scenario thinking. Could urban designers and planners do better than this in imagining multi-dimensional urban (including suburban) futures at a global scale? Sure. Have they? Not yet.

Generic suburban growth would be somewhat different under each of these possible futures. For example it may be more unequal under "fortress world" and to some extent "market forces." In this situation planners would be challenged to promote equality in a context hostile to it. Suburban growth would be more regulated under "policy reform" and "new sustainability," Under "breakdown" and "eco-communalism" there is a great deal of decentralization (though it is more orderly in the latter scenario). Currently such scenariosoften focused on the big environmental and political trends of the time--deal rather less with issues such as aging populations or the details of development within cities. However, one could imagine that the approaches under the ideas of infrastructure improvement, efficiency, and diversity in Figure 7 would fit well with "new sustainability" while some of those focused on ideas related to nature and commonality would mesh with eco-communalism.

One challenge for urban designers and planners would be to judge how far their professions should push toward a making a scenario come into being-such as policy reform or new sustainability--or to focus energy on creating resilient places that can cope with any of the futures. A long-term and more global view does provide an important filter, however. Can environments be adapted as populations age or resources become more constrained? Which of these models will use fewest resources if people choose to age in place? Is a gated enclave a blip when examined in a global perspective, just one end of a very long continuum of levels of enclosure, or the leading edge of a larger trend toward inequality (Grant and Mittlesteadt 2004; Charmes 2010)? Which of the current options for urban redevelopment, such as those indicated in Figure 7, are most resilient? 


\section{Why the Global Suburban Future Matters}

The twentieth century brought dramatic changes in cities and regions that resulted in the rise of the planning profession internationally, followed by the rise of the contemporary field of urban design (Ward, 2002; Birch and Silver, 2009). The twenty-first century will have changes that equal, if not exceed, it in impact: populations that likely grow then decline, a substantially older population, environmental stress, and an ongoing tension between poverty and expectations of affluence. In a hundred years, of course, it is possible to change what seems to be normal or commonsense. People now expect to use motorized transportation to move around a city--that took far less than 100 years to achieve. With increasing life expectancies over the past century, the meaning of family has been dramatically reshaped; it will need to be again with suburban implications. There are cautionary tales from the history of design, however, of visionary changes that led to later problems.

These trends matter for urban design and planning globally. Planning and urban design have a long history of international transfer of ideas. For example a century ago the Garden City idea developed by a British thinker drew on experiences in the U.S. and Australia and was fairly quickly transferred to built projects in Japan and continental Europe among other locations (Ward, 2002; Reference 3). More recently the international influence of the Curitiba and Bogota examples of bus rapid transit shows how an idea that was implemented in a middle-income country became part of general knowledge elsewhere. For better and worse there are numerous other examples of such planning, design, and policy transfers from new towns to open space preservation (Osborne and Whittick, 1977; Frenkel and Orenstein, 2012; Watson, 2009). Connections between different parts of the world are now very obvious - from climate change to corporate investment. While each place is of course unique, these global links mean that around the world urban designers and planners are facing some similar challenges and where the challenges are different, it is important to fully understand those differences (Watson 2009).

As comprehensive thinkers engaged with multiple public problems urban designers and planners are well placed to deal with these issues as they relate to places. It can be hard for urban designers and planners to grasp the situation even within one country, let alone take a global perspective. However, the complex global nature of these topics challenges us to do just that, look beyond a traditional "commonsense" to engage with global change in this transition century. 
i This is a large literature. Reviews include Harris (2010), Nicolaides and Weise (2006), and Reference 1. The discussion about peri-urban development is reviewed in laquinta and Drescher (1990 and Adell (1999). Work on futures is discussed in Myers, and Kitsuse (2000). ii One reviewer asked how sensitive this argument is to the definition of suburbs. The basic point that suburbs are a key site for global urban development in the next century holds true for most definitions. My points about suburban diversity and the opportunities for innovative development and redevelopment are much reduced if by definition such environments as squatter settlements or transit-oriented places cannot also be suburban.

iii Metropolitan areas turned from being sites of ill-health in the $19^{\text {th }}$ century to being places where, in countries with sufficient infrastructure and substantial educational opportunities, life expectancies are longest (Montgomery et al., 2003; Satterthwaite 2007b, 3; CDC 1999).

iv It is hard to know the exact number of "million" cities as growth has often spilled beyond metropolitan boundaries, and presumably informal settlements and floating populations were undercounted. Satterthwaite (2007b) provides a number of specific examples of this kind. ${ }^{v} \mathrm{~A}$ number of such megacities also had net out migration during their recent intercensal periods and only grew, if they did, through natural increase-these included Mexico City, Sao Paulo, Buenos Aires, Kolkata, and Seoul (Satterthwaite 2007b, 2).

vi If fertility stayed at the levels of 1995 to 2000 and other assumptions were similar, the population in 2100 would be 46 billion (compared with a "high" projection of 14 billion) (UN 2004).

viiThese projections are based on data with uneven provenance, particularly in sub-Saharan Africa where many nations have not conducted a census in decades, and also rely on debatable assumptions about economic growth rates in urban areas (Cohen 2006; Satterthwaite 2007b, 9). In a globalized world the paths of local economies are not so easy to predict and there is great disagreement about the economic future of Africa, where a lot of growth may happen (Maxwell 2005).

viii In the 1990s, 70 of the 100 fastest growing cities in the world were in China, according to UN figures for metros with populations of 750,000 or more in 2009 (UN 2010b)..

ix Population flattening is pervasive in Europe; decline has been a substantial issue at the metropolitan level in the former Soviet Union and will soon become such in such places as Japan and Korea (U.N. 2010, 12)

${ }^{x}$ Between having a young population and one where older people are a huge proportion, countries experience a "demographic window" with fewer children but not yet large numbers of older people, so a large percentage of the population is working (UN 2004, 2). Europe was in this "window" stage from 1950 until recently; Africa is not projected to enter it until after 2045 (UN 2004, 2).

xi Of course in the twentieth century people have already changed their approach to aging dramatically (Costa 1998; Bisonnette and van Soest 2011).

xii Regionally there are a number of viable options--from highly dispersed to highly concentrated urban forms--although all are likely to be polycentric and have employment not only in the core. 


\section{References}

A.T. Kearny. (2010). The Urban Elite: the AT Kearney Global Cities Index 2010. http://www.atkearney.com/images/global/pdf/Urban_Elite-GCl_2010.pdf

Adell, G. 1999. Theories and models of the peri-urban interface: a changing conceptual landscape. London: Development Planning Unit, http://discovery.ucl.ac.uk/43/1/DPU PUI Adell THEORIES MODELS.pdf

Audirac, I. E. Cunningham-Sabot, S. Fol, and S.T. Moraes. (2012). Declining suburbs in Europe and Latin America. International Journal of Urban and Regional Research 36, 2: 226-244.

Barker, P. (2009). The Freedoms of Suburbia. London: Francis Lincoln.

Beard, V.A., F. Miraftab, C. Silver eds. (2008). Planning and Decentralization: Contested Spaces for Public Action in the Global South. New York: Routledge.

Berke P. (2008). The evolution of green community planning, scholarship, and practice. Journal of the American Planning Association 74, 4, 393-407.

Biddulph, M. (2000). Villages Don't Make a City. Journal of Urban Design 5, 1: 65-82.

Birch, E. and C. Silver. (2009). One hundred years of city planning's enduring and evolving connections. Journal of the American Planning Association 75, 2, 113-122.

Bissonnette, L. and A. van Soest. (2011). The Future of Retirement and Pension System: How the Public's Expectations Vary over Time and Across Socioeconomic Groups. Discussion Paper No. 5759 Born: Institute for the Study of Labor. http://ftp.iza.org/dp5759.pdf

Boyd, R. (1960). The Australian Ugliness. Melbourne: Cheshire.

Breugemann, R. (2006). Sprawl: A Compact History. Chicago: University of Chicago Press.

Castells, M. (1997). The Power of Identity. Malden, MA: Blackwell.

CDC. (1999). Ten great public health achievements-United States, 1900-1999. Morbidity and Mortality Weekly Report 48, 12, 241-243

http://www.cdc.gov/mmwr/preview/mmwrhtml/00056796.htm

Chandler, T. (1987). Four Thousand Years of Urban Growth: An Historical Census. Lewiston, NY: Edward Mellen.

Chapin, T.S. (2012). From growth controls, to comprehensive planning, to smart growth: planning's emerging fourth wave. Journal of the American Planning Association 78, 1: 515.

Charmes, E. (2010). Cul-de-sacs, superblocks and environmental areas as supports of residential territorialization. Journal of Urban Design 15, 3: 357-374.

Chattopadhyay, S. (2012). Introduction: the historical legacy of suburbs in South Asia. Urban History 39, 1, 51-55.

Clapson, M. and R. Hutchinson eds. (2010) Suburbanization in Global Society. Bingley, UK: Emerald.

CIA. (2011). World Fact Book Online. https://www.cia.gov/library/publications/the-worldfactbook/rankorder/2102rank.html

City Mayors.com. (2006). The world's fastest growing cities and urban areas from 2006 to 2020. http://www.citymayors.com/statistics/urban_growth1.html

Clapson, M. (2003). Suburban Century: Social Change and Urban Growth in England and the U.S.A. Oxford: Berg.

Cohen, B. (2006). Urbanization in developing countries: Current trends, future projections, and key challenges for sustainability. Technology in Society 28, 63-80. 
Costa, D. (1998). The Evolution of Retirement: An American Economic History, 1880-1990. Chicago: University of Chicago Press.

Crane, R. and J. Landis. (2010). Introduction to the special issue. Journal of the American Planning Association 76, 4, 389-401.

Crewe, K, and A. Forsyth. (2011). Compactness and connection in environmental design: insights from ecoburbs and ecocities for design with nature. Environment and Planning B 38, 2, 267-288.

Davis, M. (2006). Planet of Slums. London: Verso.

Dollar, D. (2005). Globalization, poverty, and inequality since 1980. The World Bank Research Observer 20, 2, 145-175.

Dunham-Jones, E. and J. Williamson. 2009. Retrofitting Suburbia. New York: Wiley.

Eichler, E., and M. Kaplan. (1967). The Community Builders. Berkeley: University of California Press.

Fishman, R. (2003). Global Suburbs. University of Michigan working paper, URRC-0301: http://sitemaker.umich.edu/urrcworkingpapers/all_urrc_working_papers\&mode=single \&recordID=308464\&nextMode=list

Forsyth, A. and K. Crewe. (2009). A typology of comprehensive designed communities since the second world war. Landscape Journal 28, 1, 56-78.

Forsyth. A. (2005). Reforming Suburbia. Berkeley: University of California Press.

Frenkel, A. and D.E. Orenstein. (2012). Can urban growth management work in an era of political and Economic Change. Journal of the American Planning Association 78, 1, 1633.

Friedan, B.(1963). The Feminine Mystique. New York: Norton.

Gans, H. (1963). Effects of the move from city to suburb. In The Urban Condition, Leonard Duhl ed. New York: Basic Books.

Gans, H. (2009). Imagining the suburban future. Robert A. Catlin Memorial Lecture, Bloustein School of Planning and Public Policy. Rutgers, February 5: http://policy.rutgers.edu/news/events/Gans remarks.pdf

Global and World Cities. (2008). The World According to GaWC2008. http://www.lboro.ac.uk/gawc/world2008.html

Grant J. and L. Mittelsteadt. (2004). Types of gated communities. Environment and Planning B 31, 913.

Hall, P. (1999). The future of cities. Computers, Environment, and Urban Systems 23, 173-185. Hall, P. (2002). Cities of Tomorrow. $3^{\text {rd }}$ Edition. New York: Wiley.

Harris, R. \& Larkham, P.J. (1999). Suburban foundation, form and function. In Harris, R. \& P. Larkham (Eds). Changing Suburbs. Foundation, Form and Function (pp. 1-31).. New York: E. \& F.N. Spon.

Harris, R. (2010). Meaningful types in a world of suburbs. In M Clapson and R. Hutchinson eds. Suburbanization in Global Society. Bingley, UK: Emerald.

Harvey, D. (1996). Justice, Nature, and the Geography of Difference. Cambridge: Blackwell. Hayden, D. (2003). Building Suburbia: Green Fields and Urban Growth, 1820-2000. New York: Pantheon Books. 
Hebert, C. E. Belsky, and N. DuBroff. (2012). The State of Mexico's Housing: Recent Progress and Continued Challenges. W12-8. Cambridge, MA: Joint Center for Housing Studies, Harvard University.

Hise, G. (1997). Magnetic Los Angeles. Baltimore: The Johns Hopkins University Press.

laquinta, D.I. and A. W. Drescher. 1999. Defining the peri-urban: rural-urban linkages and institutional connections. Rome: UN Food and Agriculture Organization, http://www.fao.org/DOCREP/003/X8050T/x8050t02.htm\#P13 2357

Ignatieff, M. (1984). The Needs of Strangers. New York: Picador.

Johnson, L.C. (2006). Style wars: revolution in the suburbs? Australian Geographer 37, 2, 259276.

Knox, P. (2005). Creating ordinary places: Slow cities in a fast world. Journal of Urban Design 10, 1, 1-11.

Krieger, A. (2006). Where and how does urban design happen? Harvard Design Magazine 24, 64-71.

Lang, J. (2005). Urban Design: A Typology of Procedures and Products. Oxford: Architectural Press.

Lara, F.L. (2011). New (Sub)Urbanism and Old Inequalities in Brazilian Gated Communities. Journal of Urban Design 16, 3: 369-380.

Leichenko, R. and W. Solecki. (2005). Exporting the American dream: the globalization of suburban consumption landscapes. Regional Studies 39, 2, 241-253.

Loukaitou-Sideris, A. (2012). Addressing the challenges of urban landscapes: normative goals for urban design. Journal of Urban Design 17, 4: 467-484.

Maher, C. (1994). Residential mobility, locational disadvantage, and spatial inequality in Australian cities. Urban Policy and Research 13, 3, 185-191.

Marcuse, P, and R. van Kempen. (2000). A changed spatial order. Globalizing Cities: A New Spatial Order? New York: Routledge.

Marcuse, P. (2006). Space in the globalizing city. In N. Brenner \& R. Keil eds. The Global Cities Reader New York: Routledge.

Martinez-Fernandez, C. I. Audirac, S. Fol, and E. Cunninghan-Sabot. (2012). Shrinking cities: urban challenges of globalization. International Journal of Urban and Regional Research $36,2,213-225$.

Maxwell, S. (2005). Exhilarating, exhausting, intriguing: The report of the Africa Commission. Development Policy Review 23, 4, 483-498.4

Meadows D.L., Randers J., Behrens W.W. (1972). The Limits to Growth: A Report for the Club of Rome's Project on the Predicament of Mankind. New York: Universe Books.

Ministry of Transport, Great Britain. (1963). Traffic in Towns: A Study of the Long Term Problems of Traffic in Urban Areas. London: Her Majesty's Stationery Office.

Montgomery, M.R., R. Stren, B. Cohen, and H. E. Reed, eds. (2003). Cities Transformed: Demographic Change and Its Implications in the Developing World. Panel on Urban Population Dynamics, National Research Council. Washington, DC: National Academies Press http://www.nap.edu/openbook.php?record_id=10693\&page $=515$

Moran, M. (2011). Opposing exclusion: the political significance of the riots in French suburbs (2005-2007). Modern and Contemporary France 19, 3, 297-312. 
Myers, D., \& Kitsuse, A. (2000). Constructing the future in planning: A survey of theories and tools. Journal of Planning Education and Research, 19, 221-231.

National Informatics Center, Government of India. (2011). District Ghaziabad. http://ghaziabad.nic.in/default.htm

Nelson, A.C. (2004). Toward a New Metropolis: The Opportunity To Rebuild America. A Discussion Paper Prepared for The Brookings Institution Metropolitan Policy Program http://www.brookings.edu/reports/2004/12metropolitanpolicy_nelson.aspx

Neuwirth, R. (2006). Shadow Cities. New York: Routledge.

Newman, P., and J. Kenworthy. (2000). Sustainable Cities. Washington, DC: Island Press.

Newman, P. T. Beatley, and H. Boyer. (2009). Resilient Cities: Responding to Peak Oil and Climate Change. Washington, DC: Island Press.

Nicolaides, B. and A. Wiese. (2006). Introduction. In B. Nicolaides. and A. Wiese eds. The Suburb Reader. New York: Routledge.

Orfield, M. (2002). American Metropolitics: The New Suburban Reality. Washington, DC: Brookings Institution Press.

Osborn, F., and A. Whittick. (1977). New Towns: Their Origins, Achievements and Progress. London: Leonard Hill.

Pillemer, K, N. Wells, L. Wagenent, R. Meador, and J. Parise. (2011). Environmental sustainability and an aging society: a research agenda. Journal of Aging and Health 23, 3, 433-453.

Popenoe, D. (1977). The Suburban Environment. Chicago: University of Chicago Press.

Prentice, T. (2006). Health, History, and Hard Choices. World Health Organization. http://www.who.int/kms/initiatives/indiana.pdf

Quay, R. (2010). Anticipatory governance. Journal of the American Planning Association 76, 4, 496-511.

Raaj, N. (2006). Ghaziabad is "India's hottest city"! The Economic Times June 29, online.

Ramey, G. and V. Ramey. (2010). The rug rat race. Brookings Papers on Economic Activity 129176.

Raskin, P, T, Banur, G. Gallopin, P. Gutman. A. Hammond, R. Kated, R. Swart.2002. Great Transition: The Promise and Lure of the Times Ahead. A report of the Global Senario Group.http://tellus.org/documents/Great_Transition.pdf

Real Estate Research Corporation. (1974). The Costs of Sprawl. Washington, DC: United States Government Printing Office.

Reference 1 omitted for anonymity.

Reference 2 omitted for anonymity.

Reference 3 omitted for anonymity.

Riesman, D. (1950). The Lonely Crowd. New Haven: Yale University Press.

Robinson, J. (2002). Global and world cities: A view from off the map. International Journal of Urban and Regional Research 26, 3, 531-554.

Satterthwaite, D. (2007a). The scale of urban change worldwide 1950-2000 and its underpinnings. IIED Human Settlements Discussion Paper. http://www.iied.org/urban/Urban_Change.html 
Satterthwaite, D. (2007b). The transition to a predominantly urban world and its underpinnings. IIED Human Settlements Discussion Paper.

http://www.iied.org/pubs/display.php?o=10550IIED

Shangdongbusiness.gov.cn. No date. Heze.

http://english.shandongbusiness.gov.cn/public/area/heze/

Shell. (2008). Shell Energy Scenarios to 2050. http://www-

static.shell.com/static/public/downloads/brochures/corporate_pkg/scenarios/shell_ene rgy_scenarios_2050.pdf

Song, Y. and C. Ding, eds. (2009). Smart Urban Growth for China. Cambridge, MA: Lincoln Institute for Land Policy.

Teaford, J. (2008). The American Suburb: The Basics. New York: Routledge.

Turcotte, M. (2008). The city/suburb contrast: How can we measure it? http://www.statcan.gc.ca/pub/11-008-x/2008001/article/10459-eng.htm\#2

U.N. Department of Economic and Social Affairs. (2002). World Urbanization Prospects: The 2001 Revision. Data Tables and Highlights. New York: United Nations.

U.N. Department of Economic and Social Affairs. (2004). World Population to 2300. New York: United Nations.

U.N. Department of Economic and Social Affairs. (2010a). World Urbanization Prospects: The 2009 Revisions, Highlights. New York: United Nations.

U.N. Department of Economic and Social Affairs. (2010b). World Urbanization Prospects: The 2009 Revisions, Data-Excel Format. New York: United Nations.

U.N. Habitat. (2003). Water and Sanitation in the World's Cities; Local Action for Global Goals. Londo: Earthscan.

U.N Habitat (2010). State of the World's Cities 2010/2011: Cities for All: Bridging the Urban Divide. Nairobi: UN. Habitat.

http://www.unhabitat.org/pmss/listltemDetails.aspx?publicationID=2917

United Nations. C. (1999). The World at Six Billion. http://www.un.org/esa/population/publications/sixbillion/sixbilpart1.pdf

Vall-casas, P. Koschinsky, J., Mendoza, C. 2011. Retrofitting suburbia through pre-urban patterns: Introducing a European Perspective. Urban Design International 16, 3: 171187.

Wack, P. (1985). Scenarios: uncharted waters ahead. Harvard Business Review 63(5), 73-89.

Ward, S. (2002). Planning the Twentieth-Century City. Chichester: John Wiley.

Watson, V. (2009). 'The planned city sweeps the poor away...': Urban planning and $21^{\text {st }}$ century urbanization. Progress in Planning 72, 151-193.

Whyte, W.H. (1956). The Organization Man. New York: Simon and Schuster.

Wu, F. and N. Phelps. (2008). From suburbia to post-suburbia in China? Aspects of the transformation of the Beijing and Shanghai global city regions. Built Environment 34, 464-481.

Xue, C/Q.L., and M. Zhou. (2007). Importation and adaptation: building "one city and none towns" in Shanghai: A case study of Vittorio Gregotti's plan of Pujiang Town. Urban Design International 12: 21-40. 